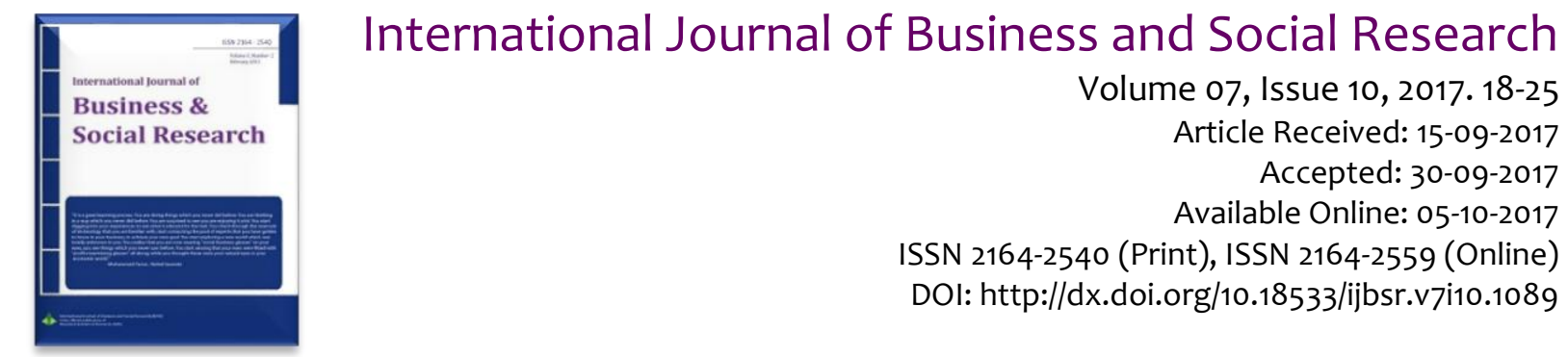

\title{
Role of Accounting Information in Assessing Stock Prices in Bangladesh
}

\author{
Nazmul Hassan', Hasan Md. Mahmood UI Haque²
}

\begin{abstract}
This paper seeks to explore the relationship between share prices and the value-relevance of accounting information. The basic Ohlson (1995) valuation model has been used to conduct the research using a sample of 93 companies from six broad industries listed on the Dhaka Stock Exchange (DSE), Bangladesh. The adjusted $\left(R^{2}\right)$ and estimated regression coefficients of accounting variables are tested in this model. Results report that both Earnings per Share (EPS) and Book Value (BV) have influential power in determining share prices. But, results of the individual effect of EPS and BV to determining share price indicate that the EPS played an increasingly considerable role in projecting share prices than that of BV. Thus, EPS has become more informative to equity investors in predicting the share prices.
\end{abstract}

Keywords: Book Value (BV), Earnings per Share (EPS), Value Relevance.

JEL Codes: D8, E20, E44.

This is an open access article under Creative Commons Attribution 4.0 License, 2017.

\section{Introduction}

Importance of accounting information relating to value relevance is a contemporary issue, as it has immense contribution to guide the investors in predicting stock prices. Beisland (2009) stated that, value relevance derived from accounting information (financial statements), influencing the stock price projections. GJerder et al. (2007), demonstrated the value relevance term as the influential power of the accounting variables, such as, earnings per share (EPS), book value per share, and return on equity (ROE) to determine the market prices of shares. Thus, the concept of the value relevance is explained as the ability of the accounting information in influencing the stock prices. This can be explained in a statistical relationship between accounting variables and share prices.

Barth et al. (2001) indicated that, an accounting values will be value relevant "only if the amount reflects information relevant to investors in valuing the firm and is measured reliable enough to be reflected in share prices." So, relevant accounting information is considered as an important pre-requisite for stock price determination. As the market information, such as, share price is considered as the benchmark for evaluating shares, value relevance enhances the knowledge of investors, and lead investors to predict future courses of actions.

\footnotetext{
${ }^{1}$ Corresponding author, Faculty, Department of Business Administration, East West University. nazmulhassan.du12@gmail.com

2 Faculty, School of Business Administration, Independent University, Bangladesh. hasanhaque@yahoo.com
} 
Early research in developed stock markets ranging from Ball and Brown (1968), Phlson (1995), Collins et al., (1997), Francis and Schipper (1999), Leve and Zarowin, (1999), Korai (2001), Khanagha, J. B. (2011) found statistical association shares market prices with accounting information. Research in the last decades, also indicates that value relevance has influential relevance in global capital markets. Related examples include UK, Netherlands, France (Alford et al., 1993), Germany (Harris et al., 1994), the UK, Canada, and Australia (Barth and Clinch, 1996), six Asian economies, namely, Indonesia, Korea, Malaysia, Philippines, Taiwan, and Thailand (Graham and King, 2000), China (Aharony et al., 2000; Chen et al., 2001; Haw et al., 1999; Lin and Chen, 2005; Liu and Liu, 2007; Samia and Zhou, 2004, and 14 European countries (Aharony, Barniv and Falk, 2010).

In Malaysia, Pirie and Smith (2008) provide evidence that the two accounting variables summarizing the income statement and the balance sheet (earnings and book value) are significant factors in the valuation process.

Increasing economic growth of South East Asian countries has become a new place for more indepth analysis of capital markets, role of accounting information, and accounting research. Though there are a lot of studies found in existing literatures, but most of them has been done on developed countries capital markets. Few studies conducted on value relevance of accounting information on South East Asian countries. Objective of this study is to investigate the relevance of accounting information in predicting share prices in Bangladesh. This study aims to answer two important questions. First, whether book values (BV) and earnings per share (EPS) are important in predicting share prices by the investors; Second, whether individual role of book value (BV) or earnings per share (EPS) has significant effect in predicting share prices?

The study used basic Ohlson model (1995) to measure the value relevance of earnings per share (EPS) and book value (BV) on share price prediction. However, other studies also support the association of accounting information and stock prices has been declining over time (Amir \& Lev, 1996; Lev \& Zarowin, 1999; Francis \& Schipper, 1999; Brown Lo \& Lys, 1999; Core, Guay \& Van Buskirk, 2003; Cortijo \& Yezegel, 2005; Saeedi \& Ebrahimi, 2010).

\section{Literature review}

Value relevance is one of the important issues of financial statements. This is used to measure the influence of accounting variables in forecasting share prices. The term has got momentum in $215 t$ century.

Collins et Al. (1997) examined the systematic changes in the value relevance of earnings per share (EPS) and book value (BV) in the last four decades (1953-1993). The authors' estimated annual crosssectional regressions and compared adjusted $\mathrm{R}^{2}$ over time. They found that, the combined valuerelevance of earnings and book value did not decline, rather increased slightly. The evidence is contradictory to the claims with the professional literature. However, further analysis indicated that, while the incremental value relevance of earnings has declined, but it has been replaced by increasing value relevance of book values. The shift in the relative importance of earnings and book values in valuation can be explained by the increasing frequency and magnitude of one-time items, the increasing frequency of negative earnings, and changes in average firm size and intangible intensity across time.

Ely and Waymire (1999), and Francis and Schipper (1999) found a highly significant increase in the combined relevance of earnings and book value during the FASB's tenure (1973-till-date) is driven by increased incremental relevance of book values, which is similar to study conducted by Collins et al. (1997). Collins et al. (1997) and Brown et al. (1999), also found and documented that, increase in value relevance of accounting information is due to increases in the coefficient of variation of the scale factor. They showed that after controlling for this effect, the value relevance has actually declined.

Alford et al. (1993) compared the information content and timeliness of accounting earnings in 17 countries, using the US as a benchmark. The found significant differences in the usefulness of accounting earnings across the markets that exhibit different characteristics in accounting standards, disclosure practices, and corporate governance. Based on a return model, annual earnings from Australia, France, the Netherlands, and UK are found to be more informative than US counterparts. On the other hand, earnings from Denmark, Germany, Italy, Singapore, and Sweden are less value relevant than US earnings. The results for Belgium, Canada, Hong Kong, Ireland, Japan, Norway, South Africa, and Switzerland are inconclusive. 
Harris et al. (1994) compared the vale relevance of accounting measure for US and German firms matching on industry and firm size. Evidence showed similar correlations of returns/earnings model for both the countries. The earnings coefficient is larger for Germany, which is consistent with the German's conservative measurement approach. The explanatory power of book value and earnings to explain the prices is significantly lower in Germany resulting from lower value relevance of book values. A possible reason for the results has been accounted from the conservative accounting practices in Germany, which leads to uncertainty of its relevance.

King and Langli (1998) investigated the relationship between accounting numbers and stock prices across European countries; Germany, Norway, and the UK. The accounting systems in three countries differs widely. Evidence shows that the value relevance of book value and earnings is highest in the UK, and it is lowest in Germany. Moreover, the incremental and relative explanatory power of book value and earnings (EPS) differs across time ad countries. Book value (BV) explains more than earnings (EPS) in Germany and Norway than the UK.

Graham and King (2000), reports the value relevance of earnings per share (EPS) and book value (BV) in six Asian countries; Indonesia, South Korea, Malaysia, the Philippines, Taiwan, and Thailand. The authors examined the relationship using actual earnings (not predicted earnings) to empirically test Recirculation Isolation Value (RIV). The results showed differences in the value relevance of book value per share and abnormal earning across the six countries. These differences are generally consistent with differences in accounting practices.

Graham and King (2000), structured their predictions based on the accounting differences across countries. First, book values in the Philippine reflects market values of assets more closely than in Taiwan. Therefore, the authors expects that the explanatory power of book value will be greater for Philippines firms than those of Taiwanese firms. And the empirical results also support the expectations. The explanatory power of book value is highest in the Philippines and lowest in Taiwan. Second, the accounting systems of Indonesia and Malaysia are less conservative than other countries. However, the authors found that the incremental explanatory power of book value is not high in both the countries. Third, accounting system in South Korea and Taiwan is less trustworthy to clean surplus accounting, while accounting in the Philippines is most reliable. Violations of clean surplus makes the empirical calculations and residual income bias.

Collins, Maydew, and Weiss (1997) and Francis and Schipper (1999) studied value relevance of equity book value and earnings, and did not find a drop in combined value relevance. But, they found that the value relevance of earnings declines and that decrease is offset by an increase in value relevance of equities book value. Further research also validated their findings (Francis and Schipper, 1999; Chen and Zhan, 2007), and Collins et al. (1997) showed that value relevance of financial statements has increased over the past 40 years and claims that accounting fundamentals and stock performance accounting information has lost its value relevance.

The importance of accounting information can be judged by the ability of the financial information contained in the financial statements to explain stock market measures (Vishnami \& $\mathrm{Kr}$. Shah, 2008). Brown, Lo, and Lys (1999) also found that the value relevance of earnings decreases and that of equity book value increases, but found a decrease in combined value relevance. Lev and Zarowin (1999) and Balachandran and Mohanram (2011) also found a decreasing trend in the combined value relevance of earnings and equity book value.

Francis and Schipper (1999), demonstrated the idea of value relevance from four viewpoints. They are fundamental analysis view, prediction view, information view, and measurement view. In fundamental analysis view, analyst interpret accounting information as value relevant, if their changing trend is reflected in the share price trends as the same direction through its inherent value. In prediction view, accounting information is treated as relevant, if it has predictive ability to foresee the returns of the upcoming years and to project share prices. Finally, in the measurement views, relevant accounting information shows a statistical relationship between the accounting variables, such as EPS, Book Value, Dividend, and Market Price of shares.

Motivated by the market-based value-relevance literature in the U.S. and by the recent developments of accounting and stock markets in China, Chen et al. (2001) has used sample of all listed firms in the Shanghai and Shenzhen Stock Exchanges from 1991 to 1998 with available data, found and 
concluded that accounting information is value-relevant to investors in the Chinese market yet to be a mature market.

Imran and Mondal (2010) conducted a study on Dhaka stock exchange (DSE) for examining the value relevance of accounting variables on projecting stock prices. The findings of the study showed that accounting variables (Profitability, growth, firm size and dividend per share) have value relevance and affect stock prices.

A similar study has done by Al-shubiri, (2010) on the firms listed in the Amman stock to analyze the determinants of market price of stock movements using simple and multiple regression analysis. The researcher found high positive significant relationship between market price of stock and book value per share.

Using a valuation model provided by Ohlson (1995), Mostafa A. El Shamy, Metwally A. Kayed (2005) conducted the study between stock prices and both earnings and book values to measure valuerelevance of the accounting information. The study reported that earnings and book values jointly and individually are positively and significantly associated with stock prices.

Glezakos, et al. (2012) conducted a study on the Athens Stock Exchange to show the effect of earnings as measured by EPS and book values on market price of shares. The findings of the study stated that combined explanatory power of both EPS and BV increases on market price of shares but the value relevance of book value is more than that of EPS.

Ijeoma N. B. (2015) examined an empirical study on the Nigerian capital market to test whether certain accounting variables affect share prices. The study found a significant relationship between EPS, Book Value, ROE and Share Prices of listed firms on the Nigerian Stock Exchange. Thus, accounting information is value-relevant in Nigeria and plays a considerable role in projecting share price.

Wael Mostafa (2016) conducted a study on the emerging market of Egypt to examine the relation between capital market and accounting information. This study found that both individually earnings and book values significantly explain stock prices; Moreover, earnings have more explanatory power beyond book values for stock prices whereas book values do not.

Vijitha P. and Nimalathasan B. (2014) conducted a similar study on manufacturing companies in Sri Lanka to provide empirical evidence relating to the value relevance of accounting information on projecting share prices. The findings of this study revealed that accounting information has (EPS, Net Assets Value per Share, ROE and Price Earnings Ratio) and significant impact on projecting share prices.

Motivated by the market-based value-relevance literature in the U.S. and by the recent developments of accounting and stock markets in China and using a sample of all listed firms in the Shanghai and Shenzhen Stock Exchanges from 1991 to 1998 with available data, Chen at el. (2001) found and conclude that accounting information is value-relevant to investors in the Chinese market yet to mature market and the perception of inadequate accounting and financial reporting in China.

Khanagha et.al (2011) examined a similar study in Iran and found that value relevance of accounting information on projecting share prices. The findings of the study also signified that earnings per share have more explanatory power on projecting share price than that of book value of equity per share.

Nadana Abayadeera (2010) conducted a study to investigate the value relevance of financial and non-financial information in high-tech industries in Australia using Ohlson's (1995) Equity Valuation Model. The results provide evidence that book value is the most significant factor and earnings are the least significant factor in deciding share prices in high-tech industries in Australia. This finding supports the previous studies that showed that book value relevance declined in earnings but increased in book value.

\section{Research design and methodology}

We have conducted the study using a sample of 93 companies from six broad industries of Bangladesh. Industries include Bank, Cement, Pharmaceutical and Chemicals, Textile, Fuel \& Power, and Engineering. All those companies are listed on Dhaka Stock Exchange (DSE) Ltd. Secondary data has been extracted from the companies' official website, and Dhaka Stock Exchange (DSE). We have collected historical data for the companies for five years from 2012 to 2016.

The basic Ohlson (1995) valuation model is used to capture the effect of accounting variables on the market prices of shares. Estimated regression coefficients of accounting variables and adjusted $\left(\mathrm{R}^{2}\right)$ 
are used to test the relevance of accounting information in this model. In this mode, market price of shares is the independent variable and earnings per share (EPS) and book value (BV) per share are two explanatory variables.

In this study, three models have been used to test the significance of EPS and BV in forecasting share prices. Model-I, focused on combined value relevance of EPS and BV on share prices. Model-II, and Model-III, has been used to examine the explanatory power of EPS and BV independently on the share prices.

Model-I: $\quad S P_{i t}=\alpha_{0}+\alpha_{1} E P S_{i t}+\alpha_{2} B V_{i t}+\varepsilon$

Where,

SPit, is the fiscal year end stock price,

EPS, is the earnings per share

$\mathrm{BV}$, is the book value per share

Model-II: $\quad S P_{i t}=\alpha_{0}+\alpha_{1} E P S_{i t}+\varepsilon$

Model-III: $\quad S P_{i t}=\alpha_{0}+\alpha_{1} B V P S_{i t}+\varepsilon$

Model-II, includes the earnings per share (EPS), while model III includes the book value (BV) per share in forecasting share prices

Table 1: Represents the measurement of variables used in this study

\begin{tabular}{|c|c|c|}
\hline Variables & Description & Measurement \\
\hline $\begin{array}{l}\text { Share } \\
\text { price }\end{array}$ & $\begin{array}{l}\text { Market price of } \\
\text { shares }\end{array}$ & Stock prices from Dhaka Stock Exchange (DSE) from 2 \\
\hline EPS & $\begin{array}{l}\text { Earnings Per } \\
\text { Share }\end{array}$ & $\begin{array}{l}\text { Net earnings available to common shareholders divided by the } \\
\text { weighted average number of common shares outstanding at the end of } \\
\text { each year. }\end{array}$ \\
\hline BV & $\begin{array}{l}\text { Book Value Per } \\
\text { Share }\end{array}$ & $\begin{array}{l}\text { Total common shareholders equity divided by the weighted average } \\
\text { number of common shares outstanding at the end of each year. }\end{array}$ \\
\hline
\end{tabular}

\section{4. $\quad$ Results and discussions}

Table 2, presents the descriptive statistics, such as mean, standard deviation, and maximum values of the share price, earnings per share (EPS), and book value (BV) per share respectively for five years data (2012-2016) in our study. The mean value of share price is 174.52, when the mean value of earnings per share (EPS) and book value per share (BVPS) are 8.9235 and 72.17582 respectively.

Table 2: Descriptive statistics

\begin{tabular}{lrrrrr}
\hline Variables & Observations & Mean & Std. Dev. & Min & Max \\
\hline EPS & 239 & 8.92359 & 17.56633 & -5.3 & 177 \\
BV & 239 & 72.17582 & 130.9635 & -54.27 & 1271 \\
Share Price & 239 & 174.5259 & 297.6539 & 7.1 & 2947 \\
\hline
\end{tabular}

Table 3: Regression analysis

\begin{tabular}{lrrr}
\hline Model-1: $S P_{i t}=\alpha_{0}+\alpha_{1} E P S_{i t}+\alpha_{2} B V_{i t}+\varepsilon$ & & \\
\hline Variables & Co-efficient & t-statistic & p-value \\
\hline Constant & 124.6577 & 5.88 & 0.000 \\
EPS & 4.8247 & 3.34 & 0.001 \\
BV & 0.0944 & 0.49 & 0.627 \\
Adjusted R & & & 0.0915 \\
\hline
\end{tabular}

In our study, we have emphasized the influence of earnings per share (EPS), and the book value per share (BVPS) in determining the share price. Value relevance of EPS and BV has been assessed by examining the statistical significance of the slope of coefficients on EPS and BV. Model-I, used has been used to show the value relevance of EPS and BVPS in forecasting share prices. The model shows depicts coefficients and t-statistics along with p-values for two-tailed regression results. In Model-I, stock price per share is the dependent variable and EPS and BV are independent variables. The value of adjusted $\mathrm{R}^{2}$ 
is 0.915, which implies significance of explanatory power of both EPS and BV in forecasting share prices. At $95 \%$ significance level, the value of coefficient of EPS and BV are 4.8247 and 0.0944 , and the value of t-statistic are 5.88 and 3.34 respectively. All the values are acceptable at $95 \%$ significance level and proves the power of explanatory variables of EPS and BV in share price forecasting.

Table 4: Regression analysis

\begin{tabular}{lrrr}
\hline Model-II: $S P_{i t}=\alpha_{0}+\alpha_{1} E P S_{i t}+\varepsilon$ & & & \\
\hline Variable & Co-efficient & t-statistic & p-value \\
\hline Constant & 127.1373 & 6.18 & 0.000 \\
EPS & 5.3104 & 5.10 & 0.000 \\
Adjusted $\mathrm{R}^{2}$ & & & 0.0944 \\
\hline
\end{tabular}

Model-II, has been used to predict the value relevance of EPS on share price independently. Adjusted $R^{2}$ value is $9.44 \%$ that implies the influence of explanatory power of EPS in forecasting share price. Form the analysis, we found the value of coefficient of EPS is 5.31 and t-statistic is 5.08 at $95 \%$ significance level, which depicts that earnings per share (EPS) is significantly associated with share prices.

Table 5: Regression analysis

\begin{tabular}{lrrr}
\hline Model-III: $S P_{i t}=\alpha_{0}+\alpha_{1} B V P S_{i t}+\varepsilon$ & & & \\
\hline Variable & Co-efficient & t-statistic & p-value \\
\hline Constant & 135.4771 & 6.33 & 0.000 \\
BV & 0.541 & 3.77 & 0.000 \\
Adjusted $\mathrm{R}^{2}$ & & & 0.0527 \\
\hline
\end{tabular}

Model-III, the above table illustrate the results of book value (BV) to examine the influence in share price projection. The value of adjusted $R^{2}$ is $5.27 \%$, implies the influence of explanatory power of $B V$ in projecting share prices. The coefficient of BV is 0.54 , and t-statistic is 3.77 also acceptable at $95 \%$ significance level. All these lead to a conclusion that book value (BV) has value relevance in share price projection.

Comparing results of Model-II and Model-III, it is evident that Adjusted $\mathrm{R}^{2}$ of book value (BV) is $6.15 \%$, which is significantly lower than the adjusted $R^{2}$ of earnings per share (EPS) of $9.44 \%$. So, we can conclude that earnings per share (EPS) has more explanatory power in stock price determination to book value (BV).

\section{Conclusion}

This study empirically examined the value relevance of accounting information in order to examine whether certain accounting variables (earnings per share (EPS) and book value (BV) have the ability to explain the valuation of stock prices on the Dhaka Stock Exchange (DSE). In this study, basic Ohlson model (1995) has been used to investigate the relationship between the market price of the share with two accounting variables namely; earnings per share (EPS) and book value per share (BV). The adjusted $\left(R^{2}\right)$ and estimated regression coefficients of accounting variables are tested in this model.

Although existing literature has offered mixed results between the associations of value relevance of accounting variable with the market price of shares. In this study, we have found both EPS and BV have influential power on projecting share prices. But, results of individual effect of EPS and BV on determining share price indicate that the EPS plays an increasingly considerable role in projecting share prices as compare to that of BV. Thus, EPS has become more informative to equity investors in forecasting share prices.

This research is not beyond limitations. The study has been conducted during the period of 2012 to 2016 considering the samples of six different industries. The research used basic Ohlson's Model (1995) considering two accounting variables namely EPS and BV. So future research can be done considering the effect of more accounting variables such as cash flow, dividend, return on equity and asset turnover along with large sample size from financial and non-financial sectors. 


\section{Reference}

Abayadeera, N. (2010). Value Relevance of Information in Hi-tech Industries in Australia: Accounting Information and Intangible Asset Disclosures. Global Review of Accounting and Finance, 1(1), 77-99.

Beisland, L. A. (2009). A Review of the Value Relevance Literature. The Open Business Journal, 2, 7-27.

Chen, C. J., Chen, S., \& Su, X. (2001). Is accounting information value-relevant in the emerging Chinese stock market? Journal of International Accounting, Auditing and Taxation, 10(1), 1-22.

Collins, D. W., Maydew, E. L., \& Weiss, I. S. (1997). Changes in the value-relevance of earnings and book values over the past forty years. Journal of Accounting and Economics, 24(1), 39-67.

Francis, J., \& Schipper, K. (1999). Have Financial Statements Lost Their Relevance? Journal of Accounting Research, 37(2), 319.

Glezakos, M., Mylonakis, J., \& Kafouros, C. (2012). The Impact of Accounting Information on Stock Prices: Evidence from the Athens Stock Exchange. International Journal of Economics and Finance, 4(2).

Gjerde, O., Knivsfla, K., \& Saettem, F. (2008). The value-relevance of adopting IFRS: Evidence from 145 NGAAP restatements. Journal of International Accounting, Auditing and Taxation, 17(2), 92-112.

Khanagha, J. B., Mohamad, S., Hassan, T., \& Sori, Z. M. (2011). The impact of reforms on the value relevance of accounting information: Evidence from Iran. African Journal of Business Management, 5(1), 96-107.

Mostafa, W. (2016). The value relevance of earnings, cash flows and book values in Egypt. Management Research Review, 39(12), 1752-1778.

Mondal, M. S. A., \& Imran, M. S. (2010). Determinants of stock price: a case study on Dhaka stock exchange. International Journal of Finance, 2(3), 1-16.

Ohlson, J. A. (1995). Earnings, Book Values, and Dividends in Equity Valuation. Contemporary Accounting Research, 11(2), 661-687.

Pirie, S., \& Smith, M. (2008). Stock prices and accounting information: evidence from Malaysia. Asian Review of Accounting, 16(2), 109-133.

Ragab, A. A., \& Omran, M. M. (2006). Accounting information, value relevance, and investors' behavior in the Egyptian equity market. Review of Accounting and Finance, 5(3), 279-297.

Shamy, M. A., \& Kayed, M. A. (2005). The value relevance of earnings and book values in equity valuation: An international perspective - The case of Kuwait. International Journal of Commerce and Management, 15(1), 68-79.

Shubiri, F. N. (2010). Analysis the Determinants of Market Stock Price Movements: An Empirical Study of Jordanian Commercial Banks. International Journal of Business and Management, 5(10).

\section{Appendixes}

Table 2:

- summarize EPS BookValue StockPrice

\begin{tabular}{r|rrrrr} 
Variable & Obs & Mean & Std. Dev. & Min & Max \\
\hline EPS & 239 & 8.92359 & 17.56633 & -5.3 & 177 \\
BookValue & 239 & 72.17582 & 130.9635 & -54.27 & 1271 \\
StockPrice & 239 & 174.5259 & 297.6539 & 7.1 & 2947
\end{tabular}




\section{Table 3:}

- regress StockPrice BookValue EPS

\begin{tabular}{|c|c|c|c|c|c|}
\hline Source & S S & $d f$ & MS & Number of obs & \\
\hline Model & 2090183.84 & 2 & 1045091.92 & Prob > F & 0.0000 \\
\hline Residual & 18996096.1 & 236 & 80491.9327 & R-squared & 0.09 \\
\hline Total & 21086280 & 238 & 88597.8149 & $\begin{array}{l}\text { Ad] R-squared } \\
\text { Root MSE }\end{array}$ & 283. \\
\hline
\end{tabular}

\begin{tabular}{r|rrrrrr}
\hline StockPrice & Coef. & Std. Err. & $t$ & P $>$ t | & [95\% Conf. Interval] \\
\hline BookValue & .0944135 & .1940359 & 0.49 & 0.627 & -.2878502 & .4766772 \\
EPS & 4.824715 & 1.44661 & 3.34 & 0.001 & 1.974797 & 7.674632 \\
_cons & 124.6577 & 21.21393 & 5.88 & 0.000 & 82.86485 & 166.4506 \\
\hline
\end{tabular}

\section{Table 4:}

- regress stockPrice EPS

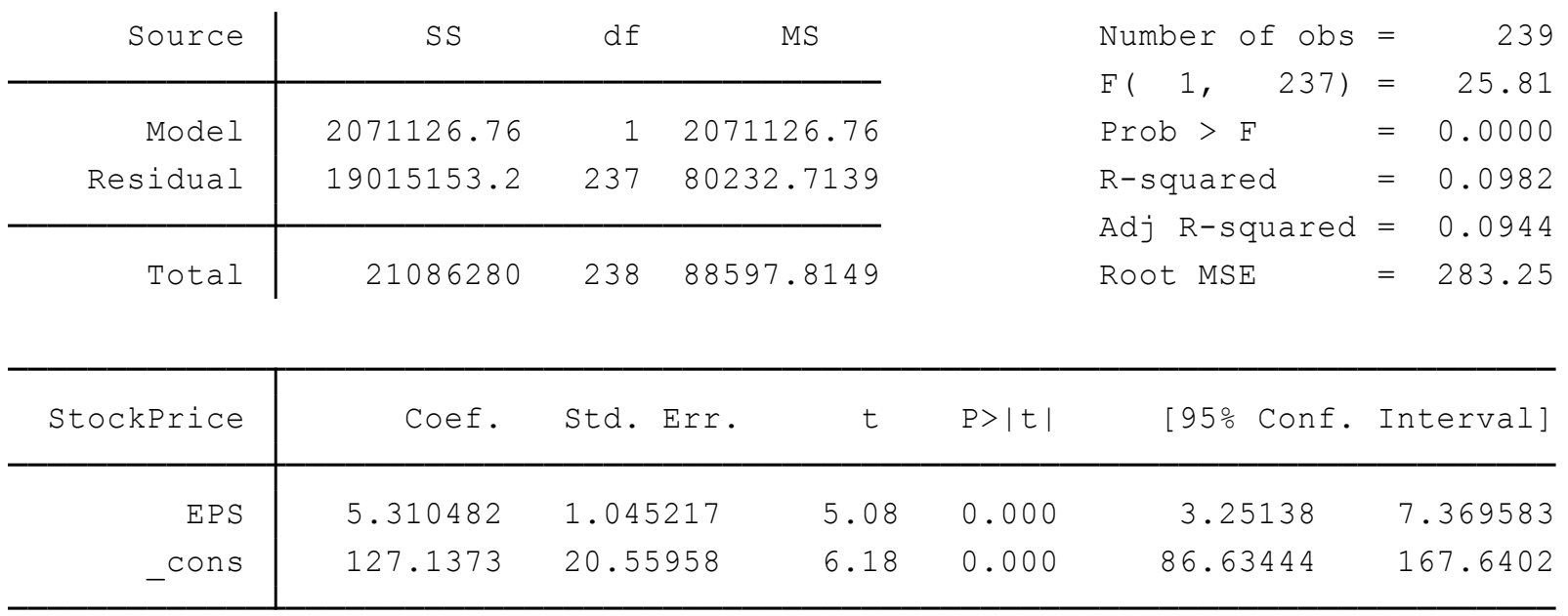

\section{Table 5:}

- regress StockPrice BookValue

\begin{tabular}{|c|c|c|c|c|c|}
\hline Source & SS & $d f$ & MS & Number of obs & 23 \\
\hline Model & 1194833.57 & 1 & 1194833.57 & Prob $>F$ & 0.0 \\
\hline Residual & 19891446.4 & 237 & 83930.1535 & R-squared & 0.05 \\
\hline Total & 21086280 & 238 & 88597.8149 & $\begin{array}{l}\text { Adj R-squared } \\
\text { Root MSE }\end{array}$ & 289 \\
\hline
\end{tabular}

\begin{tabular}{r|rrrrrr}
\hline StockPrice & Coef. & Std. Err. & $t$ & P $>|t|$ & [95\% Conf. Interval] \\
\hline BookValue & .5410222 & .1433905 & 3.77 & 0.000 & .2585395 & .8235049 \\
_cons & 135.4771 & 21.40749 & 6.33 & 0.000 & 93.30386 & 177.6504 \\
\hline
\end{tabular}

